\title{
The evaluation of the serum brain natriuretic peptide concentrations in preeclamptic and healthy pregnant women and its potential relationship with mean arterial blood pressure
}

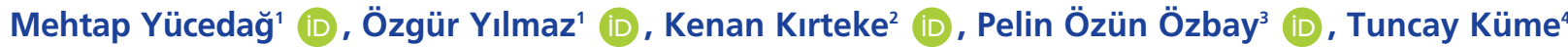 \\ ${ }^{1}$ Department of Gynecology and Obstetrics, Manisa City Hospital, Manisa, Turkey \\ ${ }^{2}$ Department of Gynecology and Obstetrics, Faculty of Medicine, Manisa Celal Bayar University, Manisa, Turkey \\ ${ }^{3}$ Obstetrics and Gynecology Clinic, Aydin Liva Hospital, Aydin, Turkey \\ ${ }^{4}$ Department of Clinical Biochemistry, Faculty of Medicine, Dokuz Eyliil University, İzmir, Turkey
}

\begin{abstract}
Objective: In this study, we aimed to investigate the correlation between serum brain natriuretic peptide (BNP) concentrations and blood pressure levels by comparing serum brain natriuretic peptide (BNP) concentrations in preeclamptic and normotensive pregnant women and to assess its potential role in the preeclampsia pathogenesis. Methods: A total of 48 preeclamptic and 39 normotensive patients were included in the study prospectively. Systolic diastolic and mean arterial blood pressure of the pregnant women were measured. Serum BNP concentrations were measured by enzyme immunoassay method. The variable differences between the groups were analyzed by independent samples t-test. Potential correlations between the variables were assessed by Pearson's correlation analysis.

Results: There was no difference between the groups in terms of age $(26.18 \pm 11.49$ years vs. $26.04 \pm 14.06$ years), gestational age $(31.59 \pm$ 6.94 weeks vs. $30.17 \pm 5.72$ weeks), parity $(2.62 \pm 1.4$ vs. $2.53 \pm 1.82)$ and body mass index $\left(30.71 \pm 16.33 \mathrm{~kg} / \mathrm{m}^{2}\right.$ vs. $\left.30.09 \pm 13.82 \mathrm{~kg} / \mathrm{m}^{2}\right)(\mathrm{p}>0.05)$. Systolic $(148.66 \pm 61.82 \mathrm{mmHg}$ vs. $126.44 \pm 97.47 \mathrm{mmHg} ; \mathrm{p}=0.015)$, diastolic $(81.19 \pm 52.25 \mathrm{mmHg}$ vs. $97.29 \pm 14.27 \mathrm{mmHg}$; $=0.019)$ and mean arterial pressure $(113.97 \pm 41.76 \mathrm{mmHg}$ vs. $96.26 \pm 27.25$ $\mathrm{mmHg} ; \mathrm{p}<0.001)$ levels were higher in the pregnant women complicated with preeclampsia. In addition, serum BNP concentrations were also higher in the preeclamptic pregnant women than the control group $(139.42 \pm 62.19 \mathrm{pg} / \mathrm{mL}$ vs. $99.28 \pm 19.32 \mathrm{pg} / \mathrm{mL} ; \mathrm{p}=0.028)$. BNP levels were significantly associated with only mean arterial pressure $(\beta=0.241, \mathrm{p}=0.037)$. Also, there was a significant positive correlation between BNP levels and mean arterial pressure $(\mathrm{r}=0.406$, $\mathrm{p}=0.002$ ).

Conclusion: We recommend further prospective studies with wider populations to assess whether BNP levels, which increase in preeclampsia, are associated with blood pressure levels or not.
\end{abstract}

Keywords: Pregnancy, preeclampsia, brain natriuretic peptide, mean arterial blood pressure.
Özet: Serum beyin natriüretik peptid

konsantrasyonlarının preeklamptik ve sağlıklı gebe kadınlarda değerlendirilmesi ve ortalama arteryel kan basıncı ile arasındaki ilişki

Amaç: Bu çalışmada preeklamptik ve normotansif gebe kadınlar arasında serum beyin natriüretik peptid (BNP) konsantrasyonlarını kıyaslayarak bu olgulardaki kan basıncı değerleri ile arasındaki ilişkinin incelenmesi ve preeklampsi patogenezindeki olası yerinin değerlendirilmesi amaçlandı.

Yöntem: 48 preeklamptik ve 39 normotensif gebe kadın prospektif olarak çalışmaya dahil edildi. Gebelerin sistolik diastolik ve ortalama arteryel kan basınçları saptand. Serum BNP konsantrasyonları enzim immunoassay yöntemi ile ölçüldü. Gruplar arasındaki değişkenlerin farklılıkları bağımsız örnekler t testi ile incelendi. Değişkenler arasındaki olası birliktelikler ise Pearson'un korelasyon analizi ile değerlendirildi.

Bulgular: Gruplar arasında yas $(26.18 \pm 11.49$ yla karșlık $26.04 \pm 14.06$ yil), gestasyonel yaş ( $31.59 \pm 6.94$ haftaya karşıllik $30.17 \pm 5.72$ hafta), parite $(2.62 \pm 1.4$ 'e karşılık $2.53 \pm 1.82)$ ve vücut kitle indeksi $(30.71 \pm 16.33$ $\mathrm{kg} / \mathrm{m}^{2}$ ye karşlık $30.09 \pm 13.82 \mathrm{~kg} / \mathrm{m}^{2}$ ) yönünden farklılık bulunmuyordu (p>0.05). Sistolik $(148.66 \pm 61.82 \mathrm{mmHg}$ ya karşıllk $126.44 \pm 97.47$ $\mathrm{mmHg} ; \mathrm{p}=0.015)$, diastolik $(81.19 \pm 52.25 \mathrm{mmHg}$ 'ya karşıllik $97.29 \pm$ $14.27 \mathrm{mmHg} ; \mathrm{p}=0.019)$ ve ortalama arteryel basinç $(113.97 \pm 41.76$ mmHg'ya karşlık $96.26 \pm 27.25 \mathrm{mmHg} ; \mathrm{p}<0.001)$ preeklampsi ile komplike gebe kadınlarda daha yüksekti. Ilave olarak serum BNP konsantrasyonları da preeklamptik gebe kadınlarda kontrol grubuna k1yasla daha yüksek saptandı $(139.42 \pm 62.19 \mathrm{pg} / \mathrm{mL}$ 'ye karşılık $99.28 \pm$ $19.32 \mathrm{pg} / \mathrm{mL} ; \mathrm{p}=0.028$ ). BNP düzeyleri sadece ortalama arteryel basınç ile anlamlı düzeyde birliktelik gösteriyordu ( $\beta=0.241, \mathrm{p}=0.037)$. Ayrıca BNP düzeyleri ile ortalama arteryel basınç arasında anlamlı pozitif korelasyon bulundu $(\mathrm{r}=0.406, \mathrm{p}=0.002)$.

Sonuç: Daha geniş prospektif çalışmalarda preeklampside artış gösteren BNP düzeylerinin kan basıncı değerleri ile birliktelik gösterip göstermediğinin değerlendirilmesi önerilir.

Anahtar sözcükler: Gebelik, preeklampsi, beyin natriüretik peptid, ortalama arteryel kan basinci.

Correspondence: Özgür Yılmaz, MD. Department of Gynecology and Obstetrics, Manisa City Hospital, Manisa, Turkey. e-mail: ozgur.dr@gmail.com / Received: November 25, 2019; Accepted: April 26, 2020

Please cite this article as: Yücedağ M, Yılmaz Ö, Kırteke K, Özün Özbay P, Küme T. The evaluation of the serum brain natriuretic peptide concentrations in preeclamptic and healthy pregnant women and its potential relationship with mean arterial blood pressure. Perinatal Journal 2020;28(2):57-61. doi: $10.2399 /$ prn.20.0282001

ORCID ID: M. Yücedağ 0000-0002-4382-3192; Ö. Y1lmaz 0000-0003-3440-3513; K. Kırteke 0000-0002-8205-3717; 


\section{Introduction}

Preeclampsia is characterized with vascular disorders affecting approximately $3-5 \%$ of the pregnancies, seen after 20 weeks of gestation, causing new-onset hypertension, and leading to vessel damage and at least one organ or system damage. Severe preeclampsia is the progressive form of the preeclampsia complicating approximately $0.6-1.2 \%$ of the pregnancies, and it results with impaired systemic characteristics such as elevated blood pressure (systolic blood pressure being $160 \mathrm{mmHg}$ or above, and diastolic blood pressure being $110 \mathrm{mmHg}$ and above) or renal failure, liver dysfunction (liver enzymes being two times higher than the normal upper threshold value) and persistent right upper quadrant or epigastric pain not responding to medical treatment, pulmonary edema, thrombocytopenia (platelet number being below $100 \times 10^{9} / \mathrm{L}$ ) or cerebral or visual anomalies. Preeclampsia is a systemic vascular disorder specific to pregnancy only, and may frequently progress to lifethreatening clinical conditions such as eclampsia, renal failure and HELLP syndrome (hemolysis, elevated liver enzymes, and low platelet count). Despite many theories asserted, the pathogenesis and etiology of preeclampsia is still unclear and it is believed that it is complex and associated with many factors. ${ }^{[1-3]}$

Brain natriuretic peptide (BNP) is a polypeptide released as pre-pro BNP by the cells in ventricular myocardium and its production increases as a response to inflammatory conditions. ${ }^{[4]}$ Ventricular myocytes release BNP and N-terminal pro BNP, which is a product of non-active $\mathrm{N}$-terminal fragment cleavage, into the systemic circulation as a response to stress and overstress. It has been reported that BNP levels can be used as a sensitive marker in the diagnosis of mild systolic or diastolic cardiac failure and congestive cardiac failure accompanied by left ventricular dysfunction. ${ }^{[5]}$ In addition, it was also reported that plasma BNP levels elevates in preeclamptic women compared to pregnant women and it is a marker of subclinical vascular diseases in these patients. The previous studies also reported that there is a correlation between BNP levels and other complications associated with pregnancy such as the severity of preeclampsia and preterm labor. ${ }^{[4]}$ However, it is not fully known whether this biochemical increase is associated non-specifically or directly with these pathological conditions or not. ${ }^{[5]}$ Therefore, we aimed to investigate the correlation between serum BNP concentrations and blood pressure levels of the pregnant women in our study group by comparing serum BNP concentrations in preeclamptic and normotensive pregnant women and to assess its potential role in the preeclampsia pathogenesis in this study.

\section{Methods}

This study was conducted prospectively with the pregnant women between 18 and 38 years old who admitted to the obstetrics and gynecology clinic after getting the approval of ethics committee. The gestational ages of the pregnant women were calculated according to their last menstrual periods and they were confirmed by checking the ultrasonographic measurement data, and recorded as "week + day". The heights (meter) and body weights $(\mathrm{kg})$ were measured and recorded by using standard and same scales while the pregnant women were wearing casual and light clothes. The systolic and diastolic blood pressure levels were measured of each pregnant women three times by the standard and same sphygmomanometer (OMRON M2 Intellisense HEM-7121-E; OMRON Healthcare Group, Hoofddorp, Netherlands) while they were rested for at least 20 minutes and on sitting position at least for 5 minutes, and the arithmetic means were recorded. The diagnosis of preeclampsia was established as defined in the guidelines of the American College of Obstetricians and Gynecologists (ACOG) with at least one of the following criteria accompanying hypertension (systolic blood pressure $<140 \mathrm{mmHg}$ or diastolic blood pressure $>90 \mathrm{mmHg}$ ) with an onset after the 20 weeks of gestation: proteinuria (creatinine rate $\geq 30 \mathrm{mg} / \mathrm{mmol}$ or $\geq 300 \mathrm{mg} /$ day or testing in persistent spot urine $\geq 2+$ ), renal failure (serum creatinine level which is not previous renal disease being $>106$ $\mu \mathrm{mol} / \mathrm{L}$ or above $1.1 \mathrm{mg} / \mathrm{dL}$ or doubling serum creatinine level without additional renal disease), at least two-fold elevation in the values of measured serum alanine aminotransferase or aspartate aminotransferase, neurological complications (severe headache, blurred vision or convulsion), hematologic complications (platelet number below $150 \times 10^{9} / \mathrm{L}$, coagulopathies), and fetal growth restriction. ${ }^{[3,6]}$ The pregnant women without additional health problem or proteinuria or any clinical symptoms listed above, the pregnant women with normal laboratory values whose blood pressure levels are within normal limits (blood pressure below $140 / 90 \mathrm{mmHg}$ ) were included in the healthy pregnant women group. 
The mean arterial pressure (MAP) was calculated by the formula below: $:^{[7]}$

MAP $(\mathrm{mmHg})=[$ Systolic blood pressure $(\mathrm{mmHg})+$ $2 \times$ Diastolic blood pressure $(\mathrm{mmHg})] / 3$

The pregnant women whose gestational age was below 20 weeks of gestation, the cases with multiple pregnancy, intrauterine dead fetuses, fetal or placental anomalies, hypertension without induced proteinuria, diabetes mellitus, eclampsia, and the cases with pregestational hypertension history or chronic hypertension detected before pregnancy were excluded from the study.

After the preeclamptic and healthy groups were established, $5 \mathrm{cc}$ venous blood sample was collected from each volunteer case after minimum 8-hour overnight fasting, and the serum sample was separated by centrifuging the samples. Serum BNP measurements were done by using an appropriate kit (Human Brain Natriuretic Peptide EIA Kit; RayBiotech Inc., Peachtree Corners, GA, USA) via enzyme immunoassay (EIA) method.

\section{Statistical analysis}

The variables were presented as "mean \pm standard deviation". The compliance of the data to the normal distribution was analyzed by Kolmogorov-Smirnov test, and it was seen by the analysis results that the data exhibited normal distribution $(\mathrm{p}=0.621)$. The homogeneity of the data was examined by one-way ANOVA analysis and it was seen by the analysis results that the data exhibited homogeneous distribution $(\mathrm{p}=0.49)$. The comparisons of the variables in the groups among themselves were analyzed by independent sample $t$ test. The potential cause-effect relationships between the variables were analyzed by linear regression analy- sis and the correlations between the variables were analyzed by Pearson's correlation analysis. All analyses were done by using SPSS v.16 (Statistical Package for the Social Sciences; SPSS Inc., Chicago, IL, USA) software compatible with Microsoft Windows OS. The value of $\mathrm{p}<0.05$ was considered significant.

\section{Results}

The clinical and laboratory findings of the study population are shown in the Table $\mathbf{1}$. There was no significant difference between the pregnant women in both groups in terms of age, gestational age, parity and body mass index $(\mathrm{p}>0.05)$. The systolic blood pressure levels were found significantly higher in the preeclamptic pregnant women $(148.66 \pm 61.82 \mathrm{mmHg}$ vs. $126.44 \pm 97.47 \mathrm{mmHg}$; $\mathrm{p}=0.015$ ). The diastolic blood pressure levels were significantly lower in the healthy pregnant women compared to the pregnant women complicated with preeclampsia $(81.19 \pm 52.25 \mathrm{mmHg}$ vs. $97.29 \pm 14.27 \mathrm{mmHg} ; \mathrm{p}=0.019)$. The mean arterial blood pressure values were significant-

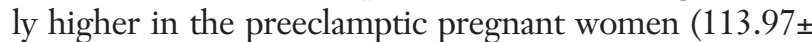
$41.76 \mathrm{mmHg}$ vs. $96.26 \pm 27.25 \mathrm{mmHg} ; \mathrm{p}<0.001)$. Serum BNP concentrations were higher in the preeclamptic pregnant women compared to the healthy pregnant women $(139.42 \pm 62.19 \mathrm{pg} / \mathrm{mL}$ vs. $99.28 \pm 19.32 \mathrm{pg} / \mathrm{mL}$; $\mathrm{p}=0.028$ ).

The potential cause-effect relationships between the variables were evaluated by the linear regression analysis. In the model created, the systolic blood pressure, diastolic blood pressure and mean arterial blood pressure levels were designed as the independent variables, and the BNP levels were designed as dependent variable. According to this model, it was found that BNP levels were only correlated significantly with the mean arterial

Table 1. The clinical and laboratory findings of the study population. *

\begin{tabular}{|c|c|c|c|}
\hline & $\begin{array}{l}\text { Preeclampsia } \\
\qquad(n=48)\end{array}$ & $\begin{array}{l}\text { Healthy } \\
(n=39)\end{array}$ & p-value \\
\hline Age & $26.18 \pm 11.49$ & $26.04 \pm 14.06$ & $>0.05$ \\
\hline Gestational age, week \pm day & $31.59 \pm 6.94$ & $30.17 \pm 5.72$ & $>0.05$ \\
\hline Parity & $2.62 \pm 1.49$ & $2.53 \pm 1.82$ & $>0.05$ \\
\hline Body mass index, $\mathrm{kg} / \mathrm{m}^{2}$ & $30.71 \pm 16.33$ & $30.09 \pm 13.82$ & $>0.05$ \\
\hline Systolic blood pressure, $\mathrm{mmHg}$ & $148.66 \pm 61.82$ & $126.44 \pm 97.47$ & 0.015 \\
\hline Diastolic blood pressure, $\mathrm{mmHg}$ & $97.29 \pm 14.27$ & $81.19 \pm 52.25$ & 0.019 \\
\hline Mean arterial pressure, $\mathrm{mmHg}$ & $113.97 \pm 41.76$ & $96.26 \pm 27.25$ & $<0.001$ \\
\hline Serum BNP concentration, pg/mL & $139.42 \pm 62.19$ & $99.28 \pm 19.32$ & 0.028 \\
\hline
\end{tabular}

* The independent samples t-test was used. The value of $p<0.05$ was considered significant. BNP: brain natriuretic peptide. 
Table 2. The results of regression analysis examining the correlation between BNP levels and systolic, diastolic and mean arterial blood pressure levels. *

\begin{tabular}{lcc} 
& $\boldsymbol{\beta}$ coefficient & p-value \\
\hline Systolic blood pressure & 0.116 & 0.52 \\
Diastolic blood pressure & 0.109 & 0.36 \\
Mean arterial pressure & 0.241 & 0.037 \\
\hline
\end{tabular}

* It was evaluated by the linear regression analysis. The BNP levels were designed as dependent variable, and the systolic, diastolic and mean arterial blood pressure levels were designed as the independent variables. The value of $p<0.05$ was considered significant.

pressure $(\beta=0.241, \mathrm{p}=0.037)$ (Table 2). Also, there was a significant positive correlation between BNP levels and mean arterial pressure $(\mathrm{r}=0.406, \mathrm{p}=0.002)$.

\section{Discussion}

In our study, we compared pregnant women without any additional health problem and the preeclamptic pregnant women who were similar in terms of maternal age and gestational age. In this comparison, we found that the serum BNP concentrations were significantly higher in the preeclamptic pregnant women (139.42 \pm $62.9 \mathrm{pg} / \mathrm{mL}$ vs. $99.28 \pm 19.32 \mathrm{pg} / \mathrm{mL}$; $\mathrm{p}=0.028$ ) while BNP levels were only correlated significantly with the mean arterial pressure.

Hypertensive diseases may develop during pregnan$\mathrm{cy}$ as a result of the inadequacies in the compliance of the volume and hemodynamic changes in pregnancy to the pregnancy-specific adaptive changes. ${ }^{[6]}$ It was reported that the maternal serum BNP levels elevated in preeclamptic pregnancies compared to healthy pregnant women. ${ }^{[8-13]}$ Ghomian et al. analyzed maternal echocardiographic parameters in their study unlike our study, and they reported that the reason of this elevation may be associated with the cardiovascular disorders such as increased vascular resistance and left ventricular pressure, reduced heart rate, left ventricular dysfunction and increased left ventricular mass index ${ }^{[4]}$ In addition, serum BNP levels were not low only in healthy pregnant women; there are also other data showing that there are differences between preeclamptic pregnant women and the pregnant women with preeclampsia exhibiting severe findings. For example, Resnik et al. compared 34 preeclamptic and 25 normotensive pregnant women in their study, and similar to our study, they found that serum BNP levels were higher in the preeclamptic pregnant women compared to the healthy pregnant women.
They also reported that the serum BNP levels were higher in the preeclamptic pregnant women with severe findings compared to the preeclamptic pregnant women. They suggested that the reason of this elevation in BNP levels may be associated with ventricular stress related with preeclampsia or subclinical cardiac disorders. ${ }^{[0]}$

On the other hand, there are different data related with the maternal BNP levels in the preeclampsia. Kaaja et al. compared the preeclamptic and healthy pregnant women who had no difference between them in terms of gestational age and parity similar to our study, but they could not find significant difference between two groups in terms of serum BNP levels unlike our study. They explained this result with the impairment of BNP in the normal diurnal variation in which there are also serum aldosterone and urinary prostaglandin metabolites as the other parameters analyzed in their study. ${ }^{[14]}$

Although mean arterial pressure exhibit decrease in the first periods of pregnancy, blood pressure levels elevate in the further periods of pregnancy and blood pressure levels reach to the pregestational levels as a result. ${ }^{\left[{ }^{[6}\right.}$ As proven in many studies, arterial blood pressure is a risk factor which is widely accepted for the development of cardiovascular diseases. ${ }^{[7,15,16]}$ On the other hand, these studies investigating risk factors for cardiovascular diseases frequently focus only on the impacts of systolic and diastolic blood pressure levels. However, these levels reflect only the fluctuations in extreme conditions. ${ }^{[17-19]} \mathrm{In}$ addition to the systolic and diastolic blood pressure levels, we also included arterial blood pressure in our study which provides more important data about the daily mean blood pressure levels instead of instant levels. Besides, other studies investigating preeclampsia examined the mean arterial pressure relatively less. The mean arterial pressure as a major component of the blood pressure provides more extensive information for the daily interpretation of blood pressure and does not require an additional cost as it can be obtained in routine clinical practice easily. ${ }^{[19]}$ Cataliotti et al. reported that the conjugated BNP they administered orally decreased the mean arterial pressure significantly. They asserted that this decrease in the mean arterial pressure occurred by the activation of cGMP via orally administered BNP. ${ }^{[20]}$

There were many limitations in our study. Firstly, relatively small study population caused the results being unable to support study hypothesis completely. Secondly, we could not include eclamptic pregnant women in our study. Lastly, we could not evaluate maternal systolic and diastolic functions echocardiographically. 


\section{Conclusion}

We found in our study that serum BNP concentrations increased in preeclamptic pregnant women. The BNP concentrations elevated in our study population were associated with the maternal mean arterial pressure. We believe that wider prospective studies evaluating $\mathrm{BNP}$ concentrations in the preeclampsia should be conducted to address the relationship between BNP levels and maternal cardiac functions.

\section{Acknowledgement}

The authors would like to thank Hasan Taylan Yilmaz, Spec. MD, and Hakan Çelik, Spec. MD., for their helps in the statistical analyses.

Conflicts of Interest: No conflicts declared.

\section{References}

1. Yu Z, Wang J, Zhang P, Ding W. Ulinastatin attenuates vascular endothelial cell damage in pregnant women with severe preeclampsia. An Acad Bras Cienc 2019;91:e20180746. [PubMed] [CrossRef]

2. Jia K, Ma L, Wu S, Yang W. Serum levels of complement factors $\mathrm{C} 1 \mathrm{q}, \mathrm{Bb}$, and $\mathrm{H}$ in normal pregnancy and severe preeclampsia. Med Sci Monit 2019;25:7087-93. [PubMed] [CrossRef]

3. Ye L, Shi MD, Zhang YP, Zhang JS, Zhu CR, Zhou R. Risk factors and pregnancy outcomes associated with retinopathy in patients presenting with severe preeclampsia: a retrospective cohort study. Medicine (Baltimore) 2020;99:e19349. [PubMed] [CrossRef]

4. Ghomian N, Vakilian F, Shahri B, Rostaminejad V, KhademRezaiyan M. Can brain natriuretic peptide predict cardiovascular complications in severe preeclampsia? A case-control study. Int J Reprod Biomed (Yazd) 2019;17(4). pii: ijrm.v17i4.4552. [PubMed] [CrossRef]

5. Borges VTM, Zanati SG, Peraçoli MTS, Poiati JR, RomãoVeiga M, Peraçoli JC, et al. Maternal left ventricular hypertrophy and diastolic dysfunction and brain natriuretic peptide concentration in early- and late-onset pre-eclampsia. Ultrasound Obstet Gynecol 2018;51:519-23. [PubMed] [CrossRef]

6. Ying W, Catov JM, Ouyang P. Hypertensive disorder of pregnancy and future maternal cardiovascular risk. J Am Heart Assoc 2018;7:e009382. [PubMed] [CrossRef]

7. Zhang $\mathrm{X}, \mathrm{Li} \mathrm{Y}$, Wang $\mathrm{Y}, \mathrm{Hu} \mathrm{K}$, Tu R, Zhang H, et al. Contribution of serum lipids as effect modifiers to a relationship disease in heart and coronary between mean arterial pressure Chinese rural population: the Henan Rural Cohort Study. BMJ Open 2019;9:e029179. [PubMed] [CrossRef]
8. Afshani N, Moustaqim-Barrette A, Biccard BM, Rodseth RN, Dyer RA. Utility of B-type natriuretic peptides in preeclampsia: a systematic review. Int J Obstet Anesth 2013;22:96-103. [PubMed] [CrossRef]

9. ResnikJL, Hong C, Resnik R, Kazanegra R, Beede J, Bhalla V, et al. Evaluation of B-type natriuretic peptide (BNP) levels in normal and preeclamptic women. Am J Obstet Gynecol 2005; 193:450-4. [PubMed] [CrossRef]

10. Tihtonen KM, Koobi T, Vuolteenaho O, Huhtala HS, Uotila JT. Natriuretic peptides and hemodynamics in preeclampsia. Am J Obstet Gynecol 2007;196:328.e1-7. [PubMed] [CrossRef]

11. Rafik Hamad R, Larsson A, Pernow J, Bremme K, Eriksson MJ. Assessment of left ventricular structure and function in preeclampsia by echocardiography and cardiovascular biomarkers. J Hypertens 2009;27:2257-64. [PubMed] [CrossRef]

12. Malhamé I, Hurlburt H, Larson L, Poppas A, Nau C, Bourjeily G, et al. Sensitivity and specificity of B-type natriuretic peptide in diagnosing heart failure in pregnancy. Obstet Gynecol 2019;134:440-9. [PubMed] [CrossRef]

13. Tanous D, Siu SC, Mason J, Greutmann M, Wald RM, Parker $\mathrm{JD}$, et al. B-type natriuretic peptide in pregnant women with heart disease. J Am Coll Cardiol 2010;56:1247-53. [PubMed] [CrossRef]

14. Kaaja RJ, Moore MP, Yandle TG, Ylikorkala O, Frampton CM, Nicholls MG. Blood pressure and vasoactive hormones in mild preeclampsia and normal pregnancy. Hypertens Pregnancy 1999;18:173-87. [PubMed] [CrossRef]

15. Cheng S, Gupta DK, Claggett B, Sharrett AR, Shah AM, Skali H, et al. Differential influence of distinct components of increased blood pressure on cardiovascular outcomes: from the atherosclerosis risk in communities study. Hypertension 2013;62:492-8. [PubMed] [CrossRef]

16. Franklin SS, Lopez VA, Wong ND, Mitchell GF, Larson MG, Vasan RS, et al. Single versus combined blood pressure components and risk for cardiovascular disease: the Framingham Heart Study. Circulation 2009;119:243-50. [PubMed] [CrossRef]

17. Falkstedt D, Koupil I, Hemmingsson T. Blood pressure in late adolescence and early incidence of coronary heart disease and stroke in the Swedish 1969 conscription cohort. J Hypertens 2008;26:1313-20. [PubMed] [CrossRef]

18. Boloukat RR, Ramezankhani A, Hasheminia M, Tasdighi E, Azizi F, Hadaegh F. Impact of blood pressure, cholesterol and glucose in the association between adiposity measures and coronary heart disease and stroke among Iranian population. Clin Nutr 2018;37:2060-7. [PubMed] [CrossRef]

19. Dart AM, Kingwell BA. Pulse pressure - a review of mechanisms and clinical relevance. J Am Coll Cardiol 2001;37:97584. [PubMed] [CrossRef]

20. Cataliotti A, Schirger JA, Martin FL, Chen HH, McKie PM, Boerrigter $\mathrm{G}$, et al. Oral human brain natriuretic peptide activates cyclic guanosine 3',5'-monophosphate and decreases mean arterial pressure. Circulation 2005;112:836-40. [PubMed] [CrossRef] 